\title{
DERET VOKAL DAN DERET KONSONAN DALAM BAHASA TUNJUNG (TONYOOI)
}

\section{THE VOWEL AND CONSONANT SERIES OF TUNJUNG (TONYOOI) LANGUAGE}

\author{
Nur Bety \\ Kantor Bahasa Provinsi Kalimantan Timur \\ Jalan Batu Cermin 25, Sempaja Utara, Samarinda 75119 \\ Pos-el: bety_salim@yahoo.com
}

*)Naskah diterima: 5 November 2021; direvisi: 5 November 2021; disetujui: 20 November 2021

\begin{abstract}
Abstrak
Penelitian ini menelaah struktur fonotaktik fonem di dalam deret vokal dan deret konsonan bahasa Tunjung. Pendekatan yang digunakan dalam penelitian ini adalah deskriptif kualitatif. Berdasarkan data yang diperoleh pada struktur fonotaktik fonem di dalam deret vokal bahasa Tunjung ditemukan 20 jenis deret vokal, yaitu/a.u/,/a.o/,/a.e/,/a.i/,/i.a/,/i.u/,/i.il,/i.e/,/i.o/,/u.o/, /u.e/, /u.a/, /u.i/, /e.o/, /e.a/, /e.u/, /o,u/, /o.i/, /o.a/, dan /o.e/. Deret vokal dalam bahasa Tunjung dapat ditemukan pada posisi awal, tengah, dan akhir sebuah kata. Deret vokal vokal dalam bahasa Tunjung memiliki potensi bisa berderet dengan vokal-vokal lain. Namun, dari data yang diperoleh tidak ditemukan deret vokal /a.a/ dan /o.o/. Adapun deret konsonan dalam bahasa Tunjung ditemukan pada posisi awal, tengah, dan akhir. Bunyi-bunyi konsonan yang berderet, yaitu /h.t/, /k.b/, /k.k/, /kng.g/, /l.d/, /.g/, /m.b/, /m.k/, /m.p/, /n.cl, /n.d/, /n.j/, /n.s/, /n.t/, / $n g . k /, / r . b /, / r . c /, / r . d /, / r . j /, / r . k /, / r . m /, / r . n g /, / r . p /, / r . s /, / r . t /, / r . w /, / s . b /, / s . k /, / s . l /, / s . p /, / t . r /$. Daya deret konsonan yang banyak ditemukan dalam data, yaitu konsonan $r$. Adapun daya deret konsonan yang paling sedikit jumlahnya, yaitu konsonan $h$ yang hanya berderet dengan konsonan $t$.
\end{abstract}

Kata kunci: deret vokal, deret konsonan, dan bahasa Tunjung

\begin{abstract}
This study examines the phonotactic structure of phonemes in the vowel and consonant series of the Tunjung language. The approach used in this research is descriptive qualitative. Based on the data obtained on the phonotactic structure of the phonemes in the Tunjung language vowel series, 20 types of vowel series were found, namely/au/, /ao/, /ae/, /ail, /ia/, /iu/, /iil, /ie/, /io/, /uo/, /ue/, /ua/, /ui /, /eo/, /ea/, /eu/, /o, u/, /oi/, /oa/, and /oe/. Vowel series in Tunjung language can be found at the beginning, middle, and end of a word. The vowel series of vowels in the Tunjung language has the potential to line up with other vowels. However, from the data obtained, no vowel series/a.a/ and/o.o/. were found. The consonant series in the Tunjung language are found in the initial, middle, and final positions. Consonant sounds that line up, namely /ht/, /kb/, /kk/, /kng.g/, /ld/, /lg/, /mb/, /mk/, /mp/, /nc/, /nd/, I

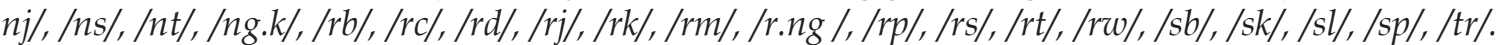
The power of the consonant series that are found in the data namely the consonant $r$. As for the power of the conconant series, the least number of consonant $h$, which only lines up with consonant $t$.
\end{abstract}

Keywords: vowel series, consonant series, and Tunjung language 


\section{PENDAHULUAN}

Indonesia terkenal dengan banyaknya bahasa daerah. Menurut data dari Badan Pengembangan dan Pembinaan Bahasa (2018), saat ini ada 718 bahasa daerah, seperti bahasa Batak, bahasa Sunda, bahasa Jawa, bahasa Benuaq, bahasa Bugis, bahasa Melayu Kutai, bahasa Kenyah, dan banyak lagi. Bahasa Tunjung (Tonyooi) adalah salah satu bahasa daerah di antara sekian banyak bahasa daerah di Indonesia.

Bahasa adalah suatu sistem tanda yang arbitrer dan konvensional. Berkaitan dengan ciri sistem, bahasa bersifat sistematis (mengikuti ketentuan atau kaidah-kaidah yang teratur) dan sistemis (bahasa merupakan suatu sistem atau subsistem-subsistem). Sebagai sebuah sistem, bahasa (termasuk bahasa daerah) terbentuk oleh suatu aturan, kaidah, dan pola-pola tertentu, baik dalam bidang bunyi, tata bentuk kata, maupun tata kalimat.

Bahasa adalah sistem bunyi ujar. Bunyi bahasa yang tidak sesuai diucapkan oleh seorang pengguna bahasa akan mengakibatkan bunyi itu tidak sesuai dengan bunyi yang sebenarnya. Pengguna bahasa perlu mempelajari bahasa lebih terinci guna menciptakan penggunaan bahasa yang lebih baik dan lebih tepat. Kesalahan berbahasa tidak hanya terjadi pada lafal tetapi juga sistem penulisan. Kebanyakan sistem penulisan tidak dapat menggambarkan bunyi yang diucapkan oleh manusia secara sempurna ketika berbicara. Sistem penulisan berfungsi sebagai pelestarian ujaran. Oleh karena itu, bunyi merupakan media bahasa yang terpenting dalam ujaran.

Dalam linguistik dikenal dua cara yang terpisah untuk mengkaji bunyi bahasa, yaitu fonetik dan fonologi. Fonetik adalah kajian dan analisis yang berhubungan dengan artikulasi, transmisi, dan persepsi bunyi-bunyi tertentu. Fonologi merupakan suatu kajian dan analisis tentang pemanfa- atan pelbagai macam bunyi bahasa oleh bahasa-bahasa dan pemanfaatan sistem-sistem untuk mengontraskan ciri-ciri bunyi (sistem fonologis) yang terdapat dalam bahasa-bahasa tersebut.

Fonetik dan fonologi mempelajari pokok masalah atau aspek yang sama dalam bahasa, yaitu bunyi bahasa sebagai hasil artikulasi yang dapat didengar, tetapi keduanya mengadakan pendekatan dari sudut pandang yang berlainan. Fonetik mempelajari bunyi bahasa tanpa mengacu kepada fungsi bunyi bahasa itu dalam bahasa tertentu), deskriptif dan dapat diklasifikasikan. Adapun fonologi memfokuskan sebuah bahasa sebagai sebuah sistem komunikasi dalam teori dan prosedur analisisnya.

Setiap bahasa mempunyai ketentuan sendiri yang berkaitan dengan kaidah kebahasaannya, termasuk di dalamnya kaidah deretan fonem. Kaidah yang mengatur deretan fonem mana yang terdapat dalam bahasa dan mana yang tidak dinamakan fonotaktik (Moeliono, 1998:52).

Fonotaktik adalah bidang fonologi atau fonemik yang mengatur tentang penjejeran fonem dalam kata. Contohnya, kata keliuq 'keracunan' dalam bahasa Tunjung (Tonyooi) memiliki enam fonem. Jejeran fonem dari kata tersebut adalah /k/, /e/, /1/, /i/, /u/, /q/. Oleh karena itu, dapat disimpulkan bahwa fonotaktik ialah cabang fonologi yang berkenaan dengan urutan fonem yang dibenarkan dalam sebuah bahasa.

Selanjutnya, Alwi (1998:28) menjelaskan bahwa dalam bahasa lisan, kata umumnya terdiri atas rentetan bunyi yang satu mengikuti yang lain. Bunyi-bunyi itu mewakili rangkaian fonem serta alofonnya. Rangkaian fonem itu tidak bersifat acak, tetapi mengikuti kaidah tertentu. Kaidah yang mengatur penjejeran fonem dalam satu kata dinamakan kaidah fonotaktik.

Bahasa Tunjung (Tonyooi) merupakan salah satu bahasa daerah yang digunakan 
dalam berkomunikasi atau berinteraksi di Kabupaten Kutai Barat dan Kabupaten Mahakam Ulu selain bahasa Benuaq, bahasa Bahau, dan bahasa Melayu Kutai. Tentunya semua aktivitas suku Tunjung (Tonyooi) selalu dilengkapi dengan bahasa. Bahasa pertama yang digunakan dalam melakukan komunikasi atau interaksi dengan masyarakat lainnya adalah bahasa ibu atau disebut dengan bahasa daerah.

Sebagai bahasa daerah, bahasa Tunjung (Tonyooi) berfungsi: (a) sebagai pendukung perkembangan kebudayaan Tunjung (Tonyooi); (b) sebagai lambang identitas masyarakat Tunjung (Tonyooi) yang merupakan salah satu suku bangsa di Indonesia; dan (c) sebagai alat perhubungan dalam keluarga dan masyarakat Tunjung (Tonyooi) dalam berkomunikasi lisan. Namun, bahasa Tunjung (Tonyooi) lama-kelamaan juga akan mengalami kepunahan, yang diakibatkan karena kalangan penggunaan bahasa daerah telah mengalami percampuran dengan bahasa lain dalam berkomunikasi dan generasi mudanya mulai jarang menggunakan bahasa Tunjung (tonyooi) tersebut sehingga jumlah penutur bahasa Tunjung (Tonyooi) mulai berkurang.

Berdasarkan hasil kajian vitalitas bahasa yang dilakukan oleh Tim Peneliti Kantor Bahasa Provinsi Kalimantan Timur (2019), status bahasa Tunjung (Tonyooi) termasuk dalam kategori bahasa daerah yang sangat terancam. Hal ini berdasarkan dari sepuluh indikator vitalitas bahasa, yaitu indikator penutur yang memiliki nilai indeks tinggi 0,47 (mengalami kemunduran) dan indikator lainnya memiliki nilai indeks di bawah angka 0,19 (terancam).

Dari hasil kajian tersebut dapat terlihat kondisi bahasa Tunjung (Tonyooi) yang berada pada kondisi terancam punah pada saat ini. Terancam punahnya suatu bahasa daerah karena sedikitnya penutur dan pihak yang mendukung untuk mengem- bangkan bahasa daerah tersebut. Hal ini akan mengakibatkan bahasa Indonesia akan kehilangan sumber keaslian dari bahasa daerah.

Bahasa Tunjung (Tonyooi) harus dipertahankan keberadaannya agar tidak mengalami kepunahan. Oleh karena itu, perlu dilakukan penelitian dan pengembangan terhadap bahasa Tunjung (Tonyooi), salah satunya dengan mengkaji struktur fonotaktik fonem di dalam deret vokal dan deret konsonan.

\section{LANDASAN TEORI \\ a. Deret Vokal}

Deret vokal adalah vokal-vokal yang berderet dalam dua suku kata yang berbeda. Deretan vokal merupakan dua vokal yang masing-masing mempunyai satu hembusan napas. Oleh karena itu, tiap-tiap vokal itu termasuk dalam suku kata yang berbeda. Pada umumnya, vokal dapat berderet dengan vokal lain dalam deretan vokal. Mmeskipun demikian, ada vokal yang tidak dapat berderet dengan vokal lain (Moeliono, 2017:62). Dengan kata lain, deret vokal adalah dua atau lebih vokal yang berjajaran yang terdapat pada suku kata yang berbeda ketika dilafalkan.

Sementara itu, Aminoedin, dkk., (1984:140) mengatakan bahwa yang dimaksud dengan deret vokal ialah dua atau lebih vokal yang berjajaran, tetapi masing-masing merupakan puncak kenyaringan ucapan. Hal ini berarti bahwa masing-masing merupakan suku yang berlainan. Adapun, Alwi, dkk. (1998:52) menjelaskan bahwa deret vokal adalah hembusan nafas yang sama atau hampir sama, kedua vokal itu termasuk dalam suku kata yang berbeda. Contoh: deret /ai/, dan /ao/ pada kata kain (kain) dan maon (rasakan) adalah deret vokal karena masing-masing terdiri atas dua suku kata, yaitu ka-in dan ma-on. 
Berdasarkan pendapat di atas dapat disimpulkan bahwa deret vokal merupakan gabungan dua atau lebih vokal yang berjajaran yang terdapat pada suku kata yang berbeda dan merupakan puncak kenyaringan ucapan. Berikut adalah contoh deret vokal yang terdapat dalam bahasa Indonesia.

$\begin{array}{lll}\text { /ii/ } & \text { /fiil/ } & \text { fill } \\ \text { /iu/ } & \text { /tiup/ } & \text { tiup } \\ \text { /io/ } & \text { /kios/ } & \text { kios } \\ \text { /ia/ } & \text { /tiap/ } & \text { tiap } \\ \text { /iE/ } & \text { /kariEr/ } & \text { karier } \\ \text { /ie/ } & \text { /mei/ } & \text { Mei } \\ \text { /ea/ } & \text { /reaktor/ } & \text { reaktor } \\ \text { /eo/ } & \text { /feodal/ } & \text { feodal } \\ \text { /aa/ } & \text { /taat/ } & \text { taat } \\ \text { /ae/ } & \text { /daerah/ } & \text { daerah } \\ \text { /ao/ } & \text { /aorta/ } & \text { aorta } \\ \text { /ai/ } & \text { /kain/ } & \text { kain } \\ \text { /au/ } & \text { /kaum/ } & \text { kaum } \\ \text { /oa/ } & \text { /swipoa/ } & \text { swipoa } \\ \text { /oi/ } & \text { /boikot/ } & \text { boikot } \\ \text { /oe/ } & \text { /koefisien/ } & \text { koefisien } \\ \text { /ui/ } & \text { /kuil/ } & \text { kuil } \\ \text { /ua/ } & \text { /puasa/ } & \text { puasa } \\ \text { /ue/ } & \text { /kue/ } & \text { kue } \\ \text { /uo/ } & \text { /kuota/ } & \text { kuota }\end{array}$

Dari daftar deret vokal di atas tampak bahwa deret /e.e/ dan /e.u/ tidak terdapat dalam bahasa Indonesia. Deret vokal itu hanya ditemukan dalam bentuk berimbuhan, seperti seekor dan seutas.

\section{b. Deret Konsonan}

Seperti halnya dengan sistem vokal yang mempunyai diftong dan deret vokal, sistem konsonan juga memiliki deret konsonan di samping gugus konsonan. Deret konsonan adalah gabungan dua konsonan yang terdapat pada suku kata yang berbeda meskipun berdampingan.
Pulgram, (1970:79) mengatakan bahwa gabungan dua konsonan atau lebih yang terjadi pada suku kata yang berbeda meskipun berdampingan disebut deret. Selanjutnya, Alwi, dkk., (1998:79) mengemukakan bahwa deret konsonan adalah gabungan dua konsonan atau lebih yang terjadi pada suku kata yang berbeda meskipun berdampingan.

Adapun, Lauder, (1996: 148) juga menyatakan deret konsonan adalah konsonan-konsonan yang berada dalam suku kata yang berbeda. Berikut adalah contoh deret konsonan yang terdapat dalam bahasa Indonesia.

$\begin{array}{ll}\text { /bd/ } & \text { sabda, abdi } \\ \text { /bn/ } & \text { ibnu } \\ \text { /bs/ } & \text { absen } \\ \text { /bt/sabtu } & \\ \text { /fs/ } & \text { fosfor, tafsir } \\ \text { /gm/ } & \text { magma, dogma } \\ \text { /gn/ } & \text { kognitif, signal } \\ \text { /hk/ } & \text { bahkan } \\ \text { /hs/ } & \text { dahsyat } \\ \text { /ht/sejahtera, tahta, bahtera } \\ \text { /kl/ } & \text { maklum,takluk, taklimat } \\ \text { /Gk/ } & \text { engkau, mungkin, } \\ \text { /sp/ } & \text { puspita, aspirasi, aspal }\end{array}$

\section{METODE PENELITIAN}

Penelitian ini adalah penelitian kualitatif dengan metode deskriptif. Moleong (2005:6) menjelaskan bahwa penelitian kualitatif adalah penelitian yang menghasilkan prosedur analisis yang tidak menggunakan prosedur analisis statistik atau cara kuantitatif lainnya. Moleong (2005:5) menjelaskan bahwa metode deskriptif mengumpulkan data yang berupa kata-kata, gambar dan bukan angka-angka. Metode ini menyarankan bahwa penelitian yang dilakukan, semata-mata hanya berdasarkan pada fakta yang ada atau fenomena yang memang secara nyata ada pada penuturnya. 
Penelitian ini berupaya memberikan gambaran objek atau sasaran sesuai dengan pemakaian penutur bahasa Tunjung (Tonyooi). Metode dan teknik penelitian ini mencerminkan kenyataan berdasarkan fakta-fakta (fact findings) yang ada di lapangan sebagaimana adanya. Sudaryanto (1988:2-3) menjelaskan bahwa metode pengumpulan data kebahasaan ada dua macam, yaitu metode kepustakaan dan metode cakap. Kedua metode itu digunakan untuk pengumpulan data dalam penelitian ini. Metode kepustakaan digunakan untuk data tulis. Adapun metode cakap digunakan untuk data lisan.

Data dalam penelitian ini berupa bunyi-bunyi bahasa Tunjung (Tonyooi) yang diperoleh dengan melakukan wawancara kepada informan menggunakan kosakata Swadesh. Data informan ini diambil dengan standar kriteria informan (Ayatrohaedi, 1983:48) sebagai berikut.

1. Penduduk asli kelahiran daerah yang diteliti.

2. Mobilitas rendah, tidak sering pergi ke luar desa tempat tinggal, dan belum pernah menetap lama di luar desa tempat tinggal.

3. Usia antara 40--60 tahun.

4. Sehat jasmani dan rohani, termasuk alat ucap dan pendengarannya.

5. Asal-usul informan harus diusahakan dari desa atau tempat yang diteliti.

6. Kemampuan informan mengenal bahasa dan dialeknya dengan baik.

7. Kemurnian bahasa informan baik, yaitu sedikit sekali terkena pengaruh dari dialek atau bahasa yang dipergunakan di daerah tetangga.

8. Berasal dari, lahir, dan besar di tempat yang diteliti.

Selain dari wawancara, sumber data penelitian juga diperoleh dari studi pustaka berupa Penelitian Kamus Dayak: Bahau,
Benuaq, Tonyooi, dan Rentenuukng-Indonesia yang disusun oleh Nathanael, dkk. (2013), dan Kamus Lima Bahasa: Benuaq--IndonesiaTonyooi--Kutai--Inggris yang disusun oleh Korrie Layun Rampan (2014).

Selanjutnya, langkah-langkah yang dilakukan dalam menganalisis deret vokal dalam bahasa Tunjung (Tonyooi), yaitu tiap-tiap vokal pada deretan vokal mendapat hembusan napas yang sama atau hampir sama; kedua vokal itu termasuk dalam dua suku kata yang berbeda. Misalnya, deretan /au/dan/ua/ pada kata la-ut dan luas. Adapun, langkah-langkah yang dilakukan dalam menganalisis deret konsonan dengan dasar bahwa gabungan dua konsonan atau lebih yang terjadi pada suku kata yang berbeda meskipun berdampingan. Misalnya, deretan /ks/ dan /nd/ pada kata paksa dan andal.

\section{HASIL DAN PEMBAHASAN}

Deret Vokal dan Konsonan Bahasa Tunjung (Tonyooi)

\section{a. Deret Vokal}

Setiap vokal pada deretan vokal mendapat hembusan napas yang sama atau hampir sama, kedua vokal itu termasuk dalam dua suku kata yang berbeda. Bunyi deretan ai dan au pada katau jain 'buruk' dan baokng 'bau' misalnya, bukanlah diftong karena baik $a$ maupun $i$ atau $a$ dan $\mathrm{u}$ masing-masing mendapat tekanan yang (hampir) sama dan membentuk suku kata tersendiri sehingga kata jain dan baokng masing-masing terdiri atas dua suku kata, yaitu ja-in dan ba-okng. Deret vokal berbeda dengan diftong. Bunyi diftong terdiri atas dua huruf yang pengucapannya dalam satu suku kata, sedangkan deret vokal adalah dua huruf vokal yang berderet dan suku katanya terpisah. Dengan demikian, deret vokal adalah dua vokal yang diucapkan dengan tekanan yang sama dan tiap vokalnya menjadi bagian suku kata yang berbeda. 


\begin{tabular}{|c|c|c|}
\hline \multicolumn{3}{|c|}{ Deret Vokal Bahasa Tunjung (Tonyooi) } \\
\hline $\begin{array}{l}\text { Deret } \\
\text { Vokal }\end{array}$ & Contoh & Arti \\
\hline /a.u/ & $\begin{array}{l}\text { /a.ur/ aur } \\
\text { /ja.ut/ jaut } \\
\text { /ja.utn/ jautn } \\
\text { /ka.u:k/ kauuk } \\
\text { /k|.la.uk/ } \\
\text { kelauq }\end{array}$ & $\begin{array}{l}\text { sibuk } \\
\text { kabur } \\
\text { awan } \\
\text { jenis kadal yang } \\
\text { besar } \\
\text { jenis buah asam } \\
\text { hutan } \\
\end{array}$ \\
\hline /a.o/ & $\begin{array}{l}\text { /ba.oq/ baoq } \\
\text { /ba.on/ baon } \\
\text { /ca.or/ caor } \\
\text { /ka.o/ kao } \\
\text { /ka.ot/ kaot } \\
\text { /la.oq/ laoq }\end{array}$ & $\begin{array}{l}\text { bau, aroma } \\
\text { bau, aroma } \\
\text { jenis sarung (untuk } \\
\text { perempuan) } \\
\text { mencuci muka } \\
\text { sendok, gayung } \\
\text { lapar }\end{array}$ \\
\hline /a.e/ & $\begin{array}{l}\text { /ga.e/gae } \\
\text { /ga.er/gaer } \\
\text { /ka.e/ kae } \\
\text { /ka.e:t/ kaeet } \\
\text { /le.ler-ma.er/ } \\
\text { leler-maer } \\
\end{array}$ & $\begin{array}{l}\text { miliknya } \\
\text { khawatir,cemas } \\
\text { memang } \\
\text { selalu, biasa } \\
\text { tak terurus, } \\
\text { berantakan } \\
\end{array}$ \\
\hline /a.i/ & $\begin{array}{l}\text { /bun.ca:r. } \\
\text { ba.ih/ } \\
\text { buncaarbaih } \\
\text { /ja.it/ jait } \\
\text { /la.ih/ laih } \\
\text { /la.itn/ laitn } \\
\text { /m|n.ta.ih/ } \\
\text { mentaih } \\
\text { /m|.ra.iq/ } \\
\text { meraiq }\end{array}$ & $\begin{array}{l}\text { berserakan } \\
\text { hampir } \\
\text { ikan lais } \\
\text { lain } \\
\text { susah, sengsara, } \\
\text { menderita } \\
\text { melerai }\end{array}$ \\
\hline /i.a/ & $\begin{array}{l}\text { /bl.ni.aq/ } \\
\text { beniaq } \\
\text { /di.apm/ diapm } \\
\text { /i.atn/ iatn } \\
\text { /jl.mi.aq/ } \\
\text { jemiaq } \\
\text { /ki.as/ kias } \\
\text { /di.an/ dian }\end{array}$ & $\begin{array}{l}\text { burung elang } \\
\text { tinggal } \\
\text { sungai } \\
\text { rumbia } \\
\text { sapu } \\
\text { kain yg dipilin } \\
\text { dan dilumuri lilin } \\
\text { madu kemudian } \\
\text { dinyalakan pada } \\
\text { saat melakukan } \\
\text { ritual belian, dll. }\end{array}$ \\
\hline
\end{tabular}

\begin{tabular}{|c|c|c|}
\hline /i.u/ & $\begin{array}{l}\text { /k|.li.ki.u/ } \\
\text { kelikiu } \\
\text { /k|.li.kau-ki.u/ } \\
\text { kelikau-kiiu } \\
\text { /k|.li.uq/ keliuq } \\
\text { /ki.ri.u/ kiriu } \\
\text { /m|.G|.li.u/ } \\
\text { mengeliu } \\
\text { /m|n.ti.u:q/ } \\
\text { mentiuuq }\end{array}$ & $\begin{array}{l}\text { sayap } \\
\text { tidak karuan } \\
\text { keracunan } \\
\text { pinggir } \\
\text { melengking } \\
\text { bunuh diri }\end{array}$ \\
\hline /i.i/ & $\begin{array}{l}\text { /gei.si.ih/ gei } \\
\text { si.ih }\end{array}$ & jenis rotan \\
\hline /i.e/ & /ji.e/ jie & sejenis guci \\
\hline /i.o/ & $\begin{array}{l}\text { /bi.on/ bion } \\
\text { /bi.oh/ bioh } \\
\text { /k|.li.o/ kelio } \\
\text { /mi.o/ mio } \\
\text { /mi.oh/ mioh }\end{array}$ & $\begin{array}{l}\text { daging yang masih } \\
\text { segar } \\
\text { baru saja } \\
\text { pergi } \\
\text { menengok } \\
\text { ladang } \\
\text { sadar, siuman } \\
\text { menyatukan yang } \\
\text { berserakan }\end{array}$ \\
\hline /u.o/ & $\begin{array}{l}\text { /bu.o/ buo } \\
\text { /lu:ok/ luuok } \\
\text { /u.ok/ uok } \\
\text { /bu.o:kng/ } \\
\text { buookng }\end{array}$ & $\begin{array}{l}\text { hujan terus-menerus } \\
\text { lubang } \\
\text { nasi yang } \\
\text { bercampur dengan } \\
\text { sayur (berkuah) } \\
\text { menyebutkan } \\
\text { atau menanyakan } \\
\text { berulang kali } \\
\end{array}$ \\
\hline /u.e/ & $\begin{array}{l}\text { /bu.eh/ bueh } \\
\text { /Gu.e.u/ ngueu }\end{array}$ & $\begin{array}{l}\text { satu, tunggal } \\
\text { memberi isyarat } \\
\text { dengan tangan agar } \\
\text { orang lain pergi atau } \\
\text { minggir }\end{array}$ \\
\hline /u.a/ & $\begin{array}{l}\text { /b|.nu.a/ benua } \\
\text { /bu.ak/ buak } \\
\text { /c|.cu.ak/ } \\
\text { cecuaq } \\
\text { /k|.lu.atn/ } \\
\text { keluatn } \\
\text { /l|.hu.atn/ } \\
\text { lehuatn } \\
\text { /ju.akG/ juakng }\end{array}$ & $\begin{array}{l}\text { kampung } \\
\text { burung hantu } \\
\text { gagap } \\
\text { tertimpa } \\
\text { bagian depan } \\
\text { bunga yang dipakai } \\
\text { dalam upacara } \\
\text { belian }\end{array}$ \\
\hline
\end{tabular}




\begin{tabular}{|c|c|c|}
\hline /u.i/ & $\begin{array}{l}\text { /hu.it/ huit } \\
\text { /kl.ku.it/ kekuit } \\
\text { /ku.i.ni/ kuini } \\
\text { /Gu.ih/ nguih } \\
\text { /Gu.it/ nguit } \\
\text { /m|.lu.ikG/ } \\
\text { meluikng }\end{array}$ & $\begin{array}{l}\text { belantik } \\
\text { terangkat pada salah } \\
\text { satu ujung } \\
\text { nama jenis mangga } \\
\text { menghajar } \\
\text { mengungkit, } \\
\text { menjungkit } \\
\text { nama jenis } \\
\text { tunbuhan yang bisa } \\
\text { dimakan }\end{array}$ \\
\hline /e.o/ & $\begin{array}{l}\text { /be.or/ beor } \\
\text { /le:ot/ leeot } \\
\text { /le.oq/ leoq } \\
\text { /le.o:n/ leoon } \\
\text { /m|.Gl.o:k/ } \\
\text { mengeook }\end{array}$ & \begin{tabular}{|l} 
nama jenis \\
cendawan/jamur \\
jalan panjang \\
sperma \\
sperma \\
keok
\end{tabular} \\
\hline /e.a/ & $\begin{array}{l}\text { /ke.ar-ke.or/ } \\
\text { kear-keor } \\
\text { /ke.ak-ke.ok/ } \\
\text { keak-keok } \\
\text { /le.a/ lea } \\
\text { /me.at/ meat } \\
\text { /ne.a:u/ neaau } \\
\text { /Ge.a:k/ ngeaak }\end{array}$ & $\begin{array}{l}\text { bergoyang-goyang } \\
\text { berbelok-belok } \\
\text { bosan } \\
\text { menindih } \\
\text { melihat } \\
\text { membuka } \\
\end{array}$ \\
\hline /e.u/ & $\begin{array}{l}\text { /ko.re.u/ koreu } \\
\text { /lo.Ge:.u/ } \\
\text { longeeu } \\
\text { /lo.se:.u/ loseeu } \\
\text { /Gu.re:.u/ } \\
\text { ngureeu } \\
\text { /Gu.we.u/ } \\
\text { nguweu } \\
\text { /Gu.se.u/ } \\
\text { nguseu } \\
\text { /GI.te.u/ ngeteu }\end{array}$ & $\begin{array}{l}\text { musim kemarau } \\
\text { berkepanjangan } \\
\text { menjulang tinggi } \\
\text { melebihi batas } \\
\text { menggerakkan } \\
\text { menggerakkan } \\
\text { tangan atau galah, } \\
\text { dan lain-lain } \\
\text { pertanda agar } \\
\text { menjauh } \\
\text { menghamburkan air } \\
\text { keluar dari dalam } \\
\text { wadahnya } \\
\text { mengibas sesuatu } \\
\text { secara terus- } \\
\text { menerus }\end{array}$ \\
\hline /o.u/ & $\begin{array}{l}\text { /pu.co:u/ } \\
\text { pucoou }\end{array}$ & Mencelupkan \\
\hline /o.i/ & /ko.ih/ koih & gesit, rajin \\
\hline /o.a/ & $\begin{array}{l}\text { /s l.lo.ar/ seloar } \\
\text { /blo.ak/ bloak } \\
\text { /co.aG/ coang } \\
\text { /lo.a:a/ loaaq } \\
\text { /lo.ah/ loah } \\
\text { /lo.an/ loan } \\
\text { /lo.akG/ loakng }\end{array}$ & $\begin{array}{l}\text { celana } \\
\text { jenis seni suara } \\
\text { baskom } \\
\text { lemak } \\
\text { mual } \\
\text { lemak } \\
\text { lubang tugalan } \\
\end{array}$ \\
\hline
\end{tabular}

\begin{tabular}{|l|l|l|}
\hline /o.e/ & $/$ / $\mid$ r.do.e: $q /$ & rapuh (tt tubuh) \\
& berdoeeq & \\
& /co.eq/ coeq & cobek \\
& /go.ar-go.er/ & longgar \\
& goar-goer & \\
& $/ 1 \mid$. so.er/ lesoer & menjuntai ke bawah \\
& $/ m \mid . G o . e k /$ & suara babi berteriak \\
& mengoek & \\
\hline
\end{tabular}

Berdasarkan tabel di atas, deret vokal dalam bahasa Tunjung (Tonyooi) dapat ditemukan pada posisi awal, tengah, dan akhir sebuah kata. Bunyi-bunyi vokal yang berderet, antara lain /a.u/, /a.o/, /a.e/, /a.i/, /i.a/, /i.u/, /i.i/, /i.e/, /i.o/, /u.o/, /u.e/, /u.a/, /u.i/, /e.o/, /e.a/, /e.u/, /o,u/, /o.i/, /o.a/, dan /o.e/. Jika kata-kata tersebut disukukatakan hasilnya seperti berikut.

/a.u/, seperti pada kata: /ja.utn/ jautn 'awan' /a.o/, seperti pada kata: /ba.on/ baon 'bau, aroma'

/a.e/, seperti pada kata: /ka.e:t/ kaeet 'selalu, biasa'

/a.i/, seperti pada kata: //ja.it/ jait 'hampir' /i.a/, seperti pada kata: /di.apm/ diapm 'tinggal' /i.u/, seperti pada kata: /k|.li.uq/ keliuq 'sayap' /i.i/, seperti pada kata: /gei si.ih/ gei siih 'jenis rotan'

/i.e/, seperti pada kata: /ji.e/ jie 'sejenis guci' /i.o/, seperti pada kata: /bi.oh/ bioh 'baru saja' /u.o/, seperti pada kata: /lu:ook/ luuok 'lubang' /u.e/, seperti pada kata: /bu.eh/ bueh 'satu, tunggal'

/u.a/, seperti pada kata: /bu.ak/ buak 'burung hantu'

/u.i/, seperti pada kata: / $k \mid \cdot k u . i t /$ kekuit 'terangkat pada salah satu ujung'

/e.o/, seperti pada kata: /le.oq/ leoq 'sperma'

/e.a/, seperti pada kata: /me.at/ meat 'menindih' /e.u/, seperti pada kata: /ko.re.u/ koreu 'musim kemarau berkepanjangan'

/o,u/, seperti pada kata: /pu.co:.u/ pucoou 'mencelupkan'

/o.i/, seperti pada kata: /ko.ih/ koih 'gesit, rajin' /o.a/, seperti pada kata: /s|.lo.ar/ seloar 'celana' /o.e/ seperti pada kata: /l|.so.er/ lesoer 'menjuntai ke bawah' 


\section{b. Deret Konsonan}

Deret konsonan adalah dua konsonan yang berbeda dan menjadi bagian suku kata yang berbeda. Deret konsonan berbeda dengan gugus konsonan. Gugus konsonan adalah dua buah konsonan atau lebih yang berurutan letaknya dalam satuan suku kata sedangkan deret konsonan merupakan dua buah konsonan atau lebih yang berderet dalam suku kata yang berlainan.

\section{Deret Konsonan Bahasa Tunjung} (Tonyooi)

\begin{tabular}{|c|c|c|}
\hline $\begin{array}{l}\text { Deret } \\
\text { Konsonan }\end{array}$ & Contoh & Arti \\
\hline /m.p/ & $\begin{array}{l}\text { / } p \mid . \text { Gam.peh/ } \\
\text { pengampeh } \\
\text { /t|.G|m. } \\
\text { pe.rek/ } \\
\text { tengemperek } \\
\text { /am.pa:p/ } \\
\text { ampaap } \\
\text { /am.pi:tn/ } \\
\text { ampiitn } \\
\text { /am.put/ } \\
\text { amput } \\
\text { /ampu:n/ } \\
\text { ampuun } \\
\text { /b|.l|m.pai/ } \\
\text { belempai } \\
\text { / b|.p|m. } \\
\text { pa:pm/ } \\
\text { bepempaapm } \\
\text { /b|.r|m.pai/ } \\
\text { berempai } \\
\text { /b|.r|m.puh/ } \\
\text { berempuh }\end{array}$ & $\begin{array}{l}\text { alat pemeras tebu } \\
\text { diomeli } \\
\text { cahaya, sinar, terang } \\
\text { alas } \\
\text { ikut, mengikuti } \\
\text { bersama } \\
\text { dengan } \\
\text { tidak memakai baju } \\
\text { menutup kemaluan } \\
\text { dengan telapak atau } \\
\text { jari tangan } \\
\text { jalan berduaan } \\
\text { saling berangkulan } \\
\text { bertemu }\end{array}$ \\
\hline /n.c/ & $\begin{array}{l}\text { / In.cu:tn/ } \\
\text { encuutn } \\
\text { / Incoq/ } \\
\text { encoq } \\
\text { /in.cuk/ } \\
\text { incuk } \\
\text { /an.car/ } \\
\text { ancar } \\
\text { /an.ca:tn/ } \\
\text { ancaatn } \\
\text { /an.ci/ anci } \\
\text { /an.cur/ } \\
\text { ancur }\end{array}$ & $\begin{array}{l}\text { asap } \\
\text { jauh } \\
\text { tukul } \\
\text { tari } \\
\text { guna-guna, pelet } \\
\text { perihal jorok, kotor } \\
\text { pancuran, talang }\end{array}$ \\
\hline
\end{tabular}

\begin{tabular}{|c|c|c|}
\hline & $\begin{array}{l}\text { / man.cak/ } \\
\text { mancak } \\
\text { /ban.cukG/ } \\
\text { bancukng } \\
\text { /b| n.co.lot/ } \\
\text { bencoloot }\end{array}$ & $\begin{array}{l}\text { tusuk } \\
\text { moncong } \\
\text { bisul }\end{array}$ \\
\hline /n.s/ & $\begin{array}{l}\text { /ben.sin/ } \\
\text { bensin } \\
\text { / } m \mid \text { n.si.git/ } \\
\text { mensigit } \\
/ m \mid n . \\
\text { s } \mid \text {.liG.kui/ } \\
\text { menyelingkui }\end{array}$ & $\begin{array}{l}\text { bensin } \\
\text { masjid } \\
\text { mengikuti dari } \\
\text { belakang }\end{array}$ \\
\hline /n.t/ & $\begin{array}{l}\text { /bin.takG/ } \\
\text { bintakng } \\
\text { /an.ta:kG/ } \\
\text { antaakng } \\
\text { /an.ta:q/ } \\
\text { antaaq } \\
\text { /an.takG/ } \\
\text { antakng } \\
\text { /an.te:k/ } \\
\text { anteek } \\
\text { /an.tuG/ } \\
\text { antung } \\
\text { /ban.tir/ } \\
\text { bantir } \\
\text { /ban.tu:t/ } \\
\text { bantuut } \\
\text { /b|.gon.tekG/ } \\
\text { begontekng } \\
\text { /b|.lun.takG/ } \\
\text { beluntakng }\end{array}$ & $\begin{array}{l}\text { bintang } \\
\text { guci besar } \\
\text { banyak } \\
\text { akan, hendak } \\
\text { sebabnya } \\
\text { arah, letak, alamat } \\
\text { masa akil balik } \\
\text { tidak meledak/ } \\
\text { meletus } \\
\text { bergantung } \\
\text { tiang (patung) untuk } \\
\text { mengikat hewan } \\
\text { kurban }\end{array}$ \\
\hline /ng.k/ & $\begin{array}{l}\text { /saG.kur/ } \\
\text { sangkur } \\
\text { / | G.ko.lakG/ } \\
\text { engkolakng } \\
\text { /k|.l|G. } \\
\text { kikG/ } \\
\text { kelengkikng } \\
\text { /aG.ka/ } \\
\text { angka } \\
\text { /aG.kai/ } \\
\text { angkai } \\
\text { /baG.kukG/ } \\
\text { bangkukng } \\
\text { /b|.l|G.kot/ } \\
\text { belengkoot } \\
\text { /maG.ka.si/ } \\
\text { mangkasi }\end{array}$ & $\begin{array}{l}\text { cangkul } \\
\text { tempat berteduh } \\
\text { lumbung padi } \\
\text { kira-kira, mungkin } \\
\text { bangkai } \\
\text { bagian atas dari } \\
\text { moncong hewan } \\
\text { bengkok } \\
\text { rendah hati }\end{array}$ \\
\hline
\end{tabular}




\begin{tabular}{|c|c|c|}
\hline & $\begin{array}{l}\text { /b|.l|G. } \\
k \mid . n a t / \\
\text { belengkenat } \\
\text { /aG.ku:i/ } \\
\text { angkuui }\end{array}$ & $\begin{array}{l}\text { makanan yg } \\
\text { tersangkut di leher } \\
\text { waktu, saat, batas }\end{array}$ \\
\hline /r.d/ & $\begin{array}{l}/ n \mid r . d a s / \\
\text { nerdas } \\
/ n \mid r . d a: t n / \\
\text { nerdaatn } \\
/ p \mid r . d a h / \\
\text { perdah }\end{array}$ & $\begin{array}{l}\text { mematikan di } \\
\text { tempatnya } \\
\text { berterus terang } \\
\text { tangkai beliung }\end{array}$ \\
\hline /r.k/ & $\begin{array}{l}\text { /k|r.kak/ } \\
\text { kerkak } \\
/ n \mid r . k a / \\
\text { nerka } \\
/ \text { G|r.kokG/ } \\
\text { ngerkokng } \\
\text { /s|r.kap/ } \\
\text { serkap }\end{array}$ & $\begin{array}{l}\text { ketiak } \\
\text { terka } \\
\text { berjongkok } \\
\text { alat penangkap } \\
\text { ikan di danau yang } \\
\text { dangkal }\end{array}$ \\
\hline /r.s/ & $\begin{array}{l}\text { /b|r.si.nak/ } \\
\text { bersinak }\end{array}$ & beracun \\
\hline$/$ r.t/ & $\begin{array}{l}\text { /k|r.tak/ } \\
\text { kertak } \\
/ \text { k|r.tikng/ } \\
\text { kertikng } \\
\end{array}$ & $\begin{array}{l}\text { kacang panjang } \\
\text { kering, garing, } \\
\text { renyah }\end{array}$ \\
\hline /r.w/ & $\begin{array}{l}/ k \mid \text { r.wi.lik/ } \\
\text { kerwilik }\end{array}$ & kincir angin \\
\hline /s.b/ & $\begin{array}{l}\text { /as.bak/ } \\
\text { asbak }\end{array}$ & asbak \\
\hline /s.k/ & $\begin{array}{l}\text { /ke.as.ke.ko/ } \\
\text { keaskeko }\end{array}$ & sudah dikerjakan \\
\hline /s.1/ & /as.li/ asli & asli \\
\hline /s.p/ & $\begin{array}{l}\text { /was.pa.da/ } \\
\text { waspada }\end{array}$ & waspada \\
\hline /1.d/ & $\begin{array}{l}\text { /bel.do:kG/ } \\
\text { beldookng }\end{array}$ & parang \\
\hline$/ \mathrm{m} \cdot \mathrm{b} /$ & $\begin{array}{l}\text { /em.ber/ } \\
\text { ember }\end{array}$ & ember \\
\hline /kng.g/ & $\begin{array}{l}\text { /ga.likG. } \\
\text { ga.nai/ } \\
\text { galikngganai }\end{array}$ & tidur-tiduran \\
\hline /n.d/ & $\begin{array}{l}\text { /gan.dum/ } \\
\text { gandum }\end{array}$ & gandum \\
\hline /r.p/ & $\begin{array}{l}\text { /g|r.patn/ } \\
\text { gerpatn }\end{array}$ & $\begin{array}{l}\text { semacam alat bantu } \\
\text { untuk berpegangan } \\
\text { pada sisi kiri atau } \\
\text { kanan } \\
\text { alat untuk meniup } \\
\text { api }\end{array}$ \\
\hline
\end{tabular}

\begin{tabular}{|c|c|c|}
\hline$/ \mathrm{r} . \mathrm{j} /$ & $\begin{array}{l}\text { /k|r.ja:q/ } \\
\text { kerjaaq } \\
/ n \mid r . j a G / \\
\text { nerjang } \\
/ t \mid r . j u G . \\
k u G / \\
\text { terjungkukng } \\
/ t \mid r . j o: q / \\
\text { terjooq }\end{array}$ & $\begin{array}{l}\text { kerja } \\
\text { terjang } \\
\text { rebah terjerungkup } \\
\text { telanjur }\end{array}$ \\
\hline /k.k/ & $\begin{array}{l}/ k|. t| k . \\
\text { ke.hen/ } \\
\text { ketekkehen }\end{array}$ & $\begin{array}{l}\text { sangat ingin akan } \\
\text { sesuatu }\end{array}$ \\
\hline /h.t/ & $\begin{array}{l}\text { / lah.ta.la/ } \\
\text { lahtala }\end{array}$ & Yang Maha Esa \\
\hline$/$ r.c/ & $\begin{array}{l}|n| r . c i k / \\
\text { nercik } \\
/ n \mid r . c u k / \\
\text { nercuk }\end{array}$ & $\begin{array}{l}\text { menjulur kaku } \\
\text { (rambut, dll.) } \\
\text { keadaan tanaman } \\
\text { yang daunnya tidak } \\
\text { subur }\end{array}$ \\
\hline$/ \mathrm{n} . \mathrm{j} /$ & $\begin{array}{l}\text { /G|n.ji.jiq/ } \\
\text { ngenjijiq }\end{array}$ & menyengir \\
\hline$/ / \lg /$ & $\begin{array}{l}/ p \mid \text { l.gag mai } / \\
\text { pelgaq mai }\end{array}$ & meluhur \\
\hline /m.k/ & $\begin{array}{l}\text { /p|m.ka:r/ } \\
\text { pemkaar }\end{array}$ & $\begin{array}{l}\text { orang yang berjasa } \\
\text { dalam sejarah dan } \\
\text { pengembangan } \\
\text { kampung }\end{array}$ \\
\hline /r.m/ & $\begin{array}{l}/ p \mid r . m a q / \\
\text { permaq } \\
/ s \mid r . m i q / \\
\text { sermiq } \\
/ s \mid r . m i n / \\
\text { sermin }\end{array}$ & $\begin{array}{l}\text { hitam } \\
\text { emper } \\
\text { cermin }\end{array}$ \\
\hline /r.ng/ & $\begin{array}{l}\text { /p|r.Ga:q/ } \\
\text { perngaaq }\end{array}$ & $\begin{array}{l}\text { pembagian tugas } \\
\text { atau pekerjaan }\end{array}$ \\
\hline /k.b/ & $\begin{array}{l}\text { / rak.ba:r/ } \\
\text { rakbaar }\end{array}$ & $\begin{array}{l}\text { adat terkait } \\
\text { pelanggaran dalam } \\
\text { upacara belian atau } \\
\text { kematian }\end{array}$ \\
\hline$/ \mathrm{r} . \mathrm{b} /$ & $\begin{array}{l}\text { /s|r.ba.na:q/ } \\
\text { serbanaaq }\end{array}$ & $\begin{array}{l}\text { memberikan nasihat } \\
\text { kepada anak } \\
\text { kandung/keluarga } \\
\text { dekat sebelum } \\
\text { meninggal }\end{array}$ \\
\hline$/$ t.r/ & $\begin{array}{l}\text { /s|t.roG.keG/ } \\
\text { setrongkeng }\end{array}$ & lampu pompa angin \\
\hline
\end{tabular}

Berdasarkan tabel di atas, dapat dijelaskan bahwa deret konsonan dalam bahasa Tunjung (Tonyooi) ditemukan pada posisi awal, tengah, dan akhir. Bunyi-bunyi 
konsonan yang berderet, yaitu /h.t/, /k.b/, /k.k/, /kng.g/, /l.d/, /l.g/, /m.b/, /m.k/, /m.p/, /n.c/, /n.d/, /n.j/, /n.s/, /n.t/, /ng.k/, /r.b/, /r.c/, /r.d/, /r.j/, /r.k/, /r.m/, /r.ng/, /r.p/, /r.s/, /r.t/, /r.w/, /s.b/, /s.k/, /s.l/, /s.p/, /t.r/.jika kata-kata tersebut disukukatakan hasilnya sebagai berikut.

/h.t/, seperti pada kata: /lah.ta.la/ lahtala 'Yang Maha Esa'

/k.b/, seperti pada kata: /rak.ba:r/ rakbar 'adat terkait pelanggaran dalam upacara

Belian atau kematian'

/k.k/, seperti pada kata: /ke.tek.ke.hen/ ketekkehen 'sangat ingin akan sesuatu'

/kng.g/, seperti pada kata:/ga.likG.ga.nail galikngganai/ 'tidur-tiduran'

/l.d/, seperti pada kata: /b|l.do:kG/ beldookng 'parang'

/l.g/, seperti pada kata: /p|l.gag mai/ pelgag mai 'leluhur'

/m.b/, seperti pada kata: /em.ber/ ember 'ember' /m.k/, seperti pada kata: /p $\mid m . k a: r /$ pemkaar 'orang yang berjasa dalam sejarah dan pengembangan kampung'

/m.p/, seperti pada kata: /am.pa:p/ ampaap 'cahaya, sinar, terang'

/n.c/, seperti pada kata: /|n.cu:tn/ encuutn 'asap'

/n.d/, seperti pada kata: /gan.dum/ gandum 'gandum'

/n.j/, seperti pada kata: /G|n.ji.jiq/ ngenjijiq 'menyengir'

/n.s/, seperti pada kata: /m|n.si.git/ mensigit 'masjid'

/n.t/, seperti pada kata: /an.ta:q/ antaaq 'banyak'

/ng.k/, seperti pada kata: |k|.l|G.kikG/ kelengkikng 'lumbung padi'

/r.b/, seperti pada kata: /s|r.ba.na:q/ serbanaaq 'memberikan nasihat kepada anak kandung atau keluarga dekat sebelum meninggal'

/r.c/, seperti pada kata: $/ n \mid$ r.cik/ nercik 'menjulur kaku (rambut, dll.)

/r.d/, seperti pada kata: /n|r.da:tn/ nerdaatn 'berterus terang' /r.j/, seperti pada kata: /t|r.jo:q/ terjooq 'telanjur' /r.k/, seperti pada kata: /k|r.kak/ kerkak 'ketiak' /r.m/, seperti pada kata: /s|r.miq/ sermiq 'emper' /r.ng/, seperti pada kata: / $p \mid r . G a: k /$ perngaak 'pembagian pekerjaan atau tugas'

/r.p/, seperti pada kata: /g|r.patn/ gerpatn 'semacam alat bantu untuk berpegangan pada sisi kiri atau kanan'

/r.s/, seperti pada kata: /b|r.si.nak/ bersinak 'beracun'

/r.t/, seperti pada kata: /k|r.tak/ kertak 'kacang panjang'

/r.w/, seperti pada kata: /k|r.wi.lik/ kerwilik 'kincir angin'

/s.b/, seperti pada kata: /as.bak/ asbak 'asbak'

/s.k/, seperti pada kata: /ke.as.ke.ko/ keaskeko 'sudah dikerjakan'

/s.1/, seperti pada kata: /as.li/ asli 'asli'

/s.p/, seperti pada kata: /was.pa.dal waspada 'waspada'

/t.r/, seperti pada kata: /s|t.roG.keG/ setrongkeng 'lampu pompa angin'

Berdasarkan data di atas deret vokal vokal dalam bahasa Tunjung (Tonyooi) memiliki potensi bisa berderet dengan vokal-vokal lain. Namun, dari data yang diperoleh tidak ditemukan deret vokal /a.a/ dan $/ 0.0 \%$

Selanjutnya, dari data tersebut juga terlihat bahwa daya deret konsonan yang banyak ditemukan dalam data, yaitu konsonan $r$. Adapun daya deret konsonan yang paling sedikit jumlahnya, yaitu konsonan $h$ yang hanya berderet dengan konsonan $t$.

\section{PENUTUP}

Berdasarkan hasil penelitian ditemukan bahwa dada struktur fonotaktik fonem di dalam deret vokal bahasa Tunjung (Tonyooi) ada 20 jenis deret vokal, yaitu /a.u/, /a.o/, /a.e/, /a.i/, /i.a/, /i.u/, /i.i/, /i.e/, /i.o/, /u.o/, /u.e/, /u.a/, /u.i/, /e.o/, /e.a/, /e.u/, /o,u/, /o.i/, /o.a/, dan /o.e/. Deret vokal dalam bahasa Tunjung 
(Tonyooi) dapat ditemukan pada posisi awal, tengah, dan akhir sebuah kata. Deret vokal yang tidak ditemukan dalam bahasa Tunjung, yaitu aa dan $o o$.

Adapun deret konsonan dalam bahasa Tunjung (Tonyooi) ditemukan pada posisi awal, tengah, dan akhir. Bunyi-bunyi konsonan yang berderet, yaitu /h.t/, /k.b/, /k.k/, /kng.g/, /l.d/, /l.g/, /m.b/, /m.k/, /m.p/, /n.c/, /n.d/, /n.j/, /n.s/, /n.t/, /ng.k/, /r.b/, /r.c/, /r.d/, /r.j/, /r.k/, /r.m/, /r.ng/, /r.p/, /r.s/, /r.t/, /r.w/, /s.b/, /s.k/, /s.l/, /s.p/, /t.r/.

Selanjutnya, penelitian ini diharapkan dapat bermanfaat dalam pengajaran bahasa Tunjung (Tonyooi) sebagai materi ajar muatan lokal. Selain itu, hasil penelitian ini diharapkan dapat dijadikan bahan untuk menyusun tata bahasa Tunjung (Tonyooi).

\section{DAFTAR PUSTAKA}

Alwi, Hasan, dkk. 1998. Tata Bahasa Baku Bahasa Indonesia (Edisi Ketiga). Jakarta: Balai Pustaka.

Aminoedin, dkk. 1984. Fonologi Bahasa Indonesia: Sebuah Studi Deskriptif. Jakarta: Pusat Pembangunan dan Pengembangan Bahasa.

Aritonang, Merry Debby, dkk. 2019. “Laporan Kajian Vitalitas Bahasa Tunjung di Desa Ngenyan Asa, Kecamatan Barong Tongkok, Kabupaten Kutai Barat". Samarinda: Kantor Bahasa Provinsi Kalimantan Timur.

Badan Pengembangan dan Pembinaan Bahasa. 2017. Kamus Besar Bahasa Indonesia (KBBI) Edisi Kelima. Jakarta: Kementerian Pendidikan dan Kebudayaan.
Badan Perencanaan Pembangunan Daerah Kabupaten Kutai Barat. 2013. Penelitian Kamus Dayak: Bahau, Benuaq, Tonyooi, dan Rentenuukng-Indonesia. Samarinda: PT Agro Teknik Konsultana.

Badan Pengembangan dan Pembinaan Bahasa. 2017. Bahasa dan Peta Bahasa. Jakarta: Kementerian Pendidikan dan Kebudayaan.

Badan Perencanaan Pembangunan Daerah Kabupaten Kutai Barat. 2015. Penelitian Etnografi Bangsawan Dayak di Kabupaten Kutai Barat. Tenggarong: CV Bintang Jaya.

Chaer, Abdul. 2009. Fonologi Bahasa Indonesia. Jakarta: Rineka Cipta.

Lauder, Multamia R.M.T. 1996. “Khazanah Fonem Bahasa Indonesia: Menilik Frekuensi dan Fonotaktiknya". Bahasa Nasional Kita dari Sumpah Pemuda ke Pesta Emas Kemerdekaan. Bandung: ITB.

Moeliono, Anton M., dkk. 2017. Tata Bahasa Baku Bahasa Indonesia (Edisi Keempat). Jakarta: Badan Pengembangan dan Pembinaan Bahasa, Kementerian Pendidikan dan Kebudayaan.

Moleong, Lexy. 2005. Metodologi Penelitian Kualitatif. Bandung: PT Remaja Rosdakarya.

Pulgram, E. 1970. Syllabe, Words, Nexus, Cursus. The Netherlands: Mouton and Co.

Rampan, Korrie Layun. 2014. Kamus Lima Bahasa: Benuaq-Indonesia-Tonyooi-Kutai-Inggris: Yogyakarta: Araska.

Sudaryanto. 1988. Metode dan Aneka Teknik Analisis Bahasa. Yogyakarta: Duta Wacana University Press. 